\title{
Is there more to folates than neural-tube defects?
}

\author{
Paul M. Finglas*, Anthony J. A. Wright, Caroline A. Wolfe, David J. Hart, Dawn M. Wright and \\ Jack R. Dainty \\ Nutrition Department, Institute of Food Research, Norwich Research Park, Colney, Norwich NR4 7UA, UK
}

\begin{abstract}
The purpose of the present paper is to review our current understanding of the chemistry and biochemistry of folic acid and related folates, and to discuss their impact on public health beyond that already established in relation to neural-tube defects. Our understanding of the fascinating world of folates and $\mathrm{C}_{1}$ metabolism, and their role in health and disease, has come a long way since the discovery of the B-vitamin folic acid by Wills (1931), and its first isolation by Mitchell et al. (1941). However, there is still much to do in perfecting methods for the measurement of folate bioavailability, and status, with a high extent of precision and accuracy. Currently, examination of the relationships between common gene polymorphisms involved in $\mathrm{C}_{1}$ metabolism and folate bioavailability and folate status, morbidity, mortality and longevity is evaluated as a series of individual associations. However, in the future, examination of the concurrent effects of such common gene polymorphisms may be more beneficial.
\end{abstract}

Folic acid: Bioavailability: $\mathrm{C}_{1}$ metabolism: Gene polymorphisms: Health and disease

Folate is a generic term for all B-vitamin compounds that exhibit a common vitamin activity based on the parent structure of folic acid (pteroyl-L-monoglutamic acid). Folates are essential for a wide range of biochemical pathways involving $\mathrm{C}_{1}$ metabolism. In particular, folates play an essential role in cell replication and pregnancy because they are required for the synthesis of purines and pyrimidines, the building blocks of DNA. Marked protection against neural-tube defects has been shown in women supplemented periconceptionally with folic acid (MRC Vitamin Study Research Group, 1991; Czeizel \& Dudas, 1992). The remethylation of homocysteine, a S-containing amino acid, intimately involves the metabolism of folate and other B-vitamins, notably vitamin $\mathrm{B}_{12}$. Elevated plasma homocysteine, a consequence of marginal folate deficiency, is an emerging risk factor for vascular disease and certain cancers (Boushey et al. 1995; Mason, 1995).

The purpose of the present paper is to review our current understanding of the chemistry and biochemistry of the vitamin, and to discuss its impact on public health. It also identifies research areas where our knowledge is limited or inadequate.

\section{Chemical forms, dietary sources and intake}

Folic acid is the most oxidised and stable form of folate and consists of an aromatic pteridine ring linked through a methylene bridge to $p$-aminobenzoic acid, and then to one L-glutamic acid residue. It occurs rarely in nature, but is the form used for vitamin supplementation and food fortification because of its greater stability and lower cost. Folates occurring naturally in body tissues and foods are mainly 5,6,7,8-tetrahydro-pteroylpolyglutamates, which contain a fully-reduced pteridine ring together with additional glutamic acid molecules linked by $\gamma$-peptide bonds. The nutritional activity of these reduced polyglutamates is expressed as long as the essential subunit structure of folic acid remains largely intact. Additionally, folates are usually $\mathrm{C}_{1}$ substituted at the $\mathrm{N}-5$ (e.g. 5-methyl, 5-formyl) or N-10 (e.g. 10-formyl) positions, or have a single $\mathrm{C}$ bridge spanning these positions (e.g. 5,10-methylene, 5,10-methenyl). Thus, there are many chemical derivatives of folic acid that exhibit a common vitamin activity (as folates), and these have been well described (Wagner, 1996; Scott, 1999).

The main dietary sources of folate are leafy green vegetables, dairy products and cereal products, especially fortified breads and breakfast cereals. Mainly as a result of the increased consumption of such fortified products, there has been a gradual increase of about $14 \%$ in folate intakes since 1980. The average folate intake from the household food supply in the UK in 1998 was $241 \mu \mathrm{g} / \mathrm{d}$ (Department of Health, 2000). An additional average of $29 \mu \mathrm{g} / \mathrm{d}$ was consumed outside the home, giving a final total average folate intake of $270 \mu \mathrm{g} / \mathrm{d}$. 
In the UK a value for the recommended daily amount (which equates to the current reference nutrient intake) was set for folate in 1979 at $300 \mu \mathrm{g} / \mathrm{d}$ for adults (Department of Health, 1979). This value was later withdrawn because of scientific uncertainties in the food folate data used to calculate intakes. In 1991 the reference nutrient intake, which is sufficient to cover the needs of most population groups, was introduced for folate and set at $200 \mu \mathrm{g} / \mathrm{d}$ for all adults, rising to $300 \mu \mathrm{g} / \mathrm{d}$ during pregnancy and $260 \mu \mathrm{g} / \mathrm{d}$ during lactation (Department of Health, 1991). These reference nutrient intakes were estimated on the basis of the relationship between dietary intakes and markers of folate status such as serum or erythrocyte folate concentrations, and liver folate concentrations at post-mortem examination. However, the current reference nutrient intake does not take into account any differences due to genetic polymorphisms of common folate enzymes.

\section{Absorption and metabolism}

Before absorption across the intestinal mucosa can take place, dietary folates (which exist predominantly as polyglutamates) need to be hydrolysed to the folate monoglutamate form in the gut lumen by a brush-border $\gamma$-glutamyl hydrolase or conjugase (folylpolyglutamate carboxypeptidase; Halsted, 1980). Human brush-border folate conjugase is a $\mathrm{Zn}$ dependent exopeptidase that catalyses the stepwise hydrolysis of folate polyglutamates (Reisenauer et al. 1977). The mucosal cells of the proximal small intestine (jejunum) then take up these monoglutamates by a saturable active energydependent carrier-mediated process at physiological concentrations, and by passive diffusion at higher concentrations (Selhub et al. 1984). Many foods contain inhibitors of the intestinal brush-border folate conjugase enzyme and/or folate transport system, which can reduce the efficiency of absorption (Tamura \& Stokstad, 1973; Butterworth et al. 1974; Babu \& Srikantia, 1976).

The efficiency of deconjugation and absorption in the gut lumen can vary considerably with the folate form, the presence of other dietary constituents and various physiological factors. Absorption is not affected by the aging process (Bailey et al. 1984), but it is markedly influenced by $\mathrm{pH}$, with a maximum at $\mathrm{pH} 6.3$ and a sharp decline between 6.3 and 7.6 (Russell et al. 1979). Some foods, such as milk and other dairy foods, contain folate-binding proteins (Ghitis, 1967; Wagner, 1985). Small amounts of folate may also be synthesised by intestinal flora in the body, but in man (unlike the rat) this source of absorbable folate is only a very minor one.

Absorbed folate monoglutamates are converted to the 5-methyltetrahydrofolic acid (5-methyl THF) form during transit through the intestinal mucosa, before onward transport into the hepatic portal vein. From here 5-methyl THF is conveyed to the systemic plasma circulation via the liver, which is thought to initially remove a sizeable proportion of the absorbed dose ('first pass effect'; Steinberg et al. 1979). The only folate form usually entering the human circulation from intestinal cells is 5-methyl THF. A review by Selhub et al. (1983) concluded that the intestine is capable of both reduction and $\mathrm{C}_{1}$ substitution (methylation) of physiological doses of

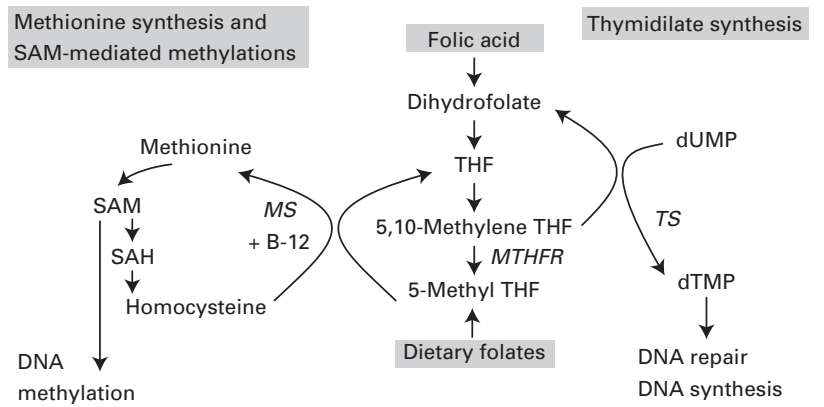

Fig. 1. $C_{1}$ metabolism, encompassing both homocysteine remethylation and thymidylate synthesis. SAM, S-adenosylmethionine; SAH, $S$-adenosylhomocysteine; MS, methionine synthase; B-12, vitamin $\mathrm{B}_{12}$; THF, tetrahydrofolic acid; MTHFR, methylenetetrahydrofolic acid; dUMP, deoxyuridine monophosphate; TS, thymidylate synthase.

folic acid (e.g. from supplements and fortified foods) before it is transported from the mucosal side to the serosal side. However, this process is limited in capacity, and folic acid uptake is itself saturable, with an additional capacity for passive diffusion. As a result, if enough folic acid is ingested ( $>280 \mu \mathrm{g}$ in one dose), unaltered folic acid may appear in the circulation (Kelly et al. 1997). With this exception, the folate form generally present in the systemic circulation is 5-methyl THF, which is then taken up by cells via folate transport systems. This form cannot be retained intracellularly, or used as a coenzyme, unless it is first metabolised by the vitamin $\mathrm{B}_{12}$-dependent enzyme methionine synthase to the tetrahydrofolate form (see Fig. 1) and then converted to a polyglutamate. Circulating folic acid, from excess intake, can also be taken up by cells and subsequently utilised after it is initially reduced, via dihydrofolate, to the tetrahydrofolate form. In man folate is mainly stored in the liver (Whitehead, 1973; Hoppner \& Lampi, 1980), which is assumed to contain $50 \%$ of the normal total body folate content of 5-20 mg. Folate undergoes substantial enterohepatic recirculation, with as much as $100 \mu \mathrm{g}$ folate undergoing biliary re-excretion each day (Herbert \& Das, 1993). Although much of this folate is reabsorbed by the small intestine (Weir et al. 1985), the efficiency of this re-absorption may be influenced by diet composition if digestion of foods happens to be concurrently in progress. Deficiencies of vitamin $\mathrm{B}_{12}$, vitamin $\mathrm{C}, \mathrm{Fe}$ and $\mathrm{Zn}$ can reduce the efficiency of folate utilisation. Folate absorption is also affected adversely by some drugs (anticonvulsants, anti-inflammatory and anti-cancer drugs, and some oral contraceptives; Institute of Medicine, 2000).

It is thought that the bioavailability of food folates averages about $50 \%$ of that for folic acid (Gregory, 1997; Bailey, 1998). Although the bioavailability of folic acid taken in the form of supplements is high, when it is consumed in the form of fortified foods the bioavailability is thought to be lower and depends on the food vehicle used for fortification. An estimate of $85 \%$ bioavailability from fortified foods was used to calculate the dietary folate equivalents in the USA (Bailey, 1998; Lewis et al. 1999). It was further calculated that folic acid taken in the form of 
fortified foods, or taken with food, is 1.7 times more bioavailable than food folates.

However, recent studies using a dual-label stable-isotope protocol have suggested that some cereal-based vehicles (especially bran) may inhibit folate absorption, i.e. below the $85 \%$ bioavailability used previously for vehicles (Finglas et al. 2002b). Another recent study has also found much higher absorption of spinach folate (79 \%) relative to a folic acid supplement, using an ilesotomy model in which the difference between folate intake and the folate content of ileostomy effluents was used to calculate absolute absorption (Konings et al. 2002).

\section{Methods for assessing folate bioavailability}

Amongst short-term protocols, comparison of the serum or plasma response to a single oral folate test dose relative to that of a folic acid reference dose has often been used for the assessment of folate bioavailability in human volunteers (Gregory, 1997, 2001). Such protocols have varied, in that they have entailed either measurement of the rate of increase, or the maximum increase, in plasma folate concentration over a period of 2-3h (Perry \& Chanarin, 1972; Lucock et al. 1989; Bower et al. 1993; Kelly et al. 1997), or measurement of the rise in plasma folate concentration (the area under the curve) over a period of $\geq 7$ h (Pietrzik et al. 1990; Prinz-Langenohl et al. 1999). These protocols have been criticised for their relative insensitivity, and because those protocols based on the rate of increase, or the maximum increase, may be flawed (Gregory, 2001). Additionally, it has not yet been confirmed whether the plasma response to a test dose derives, in its entirety, from the test dose.

The use of stable-isotope-labelling studies of folate bioavailability was developed on the premise that labelled folate molecules appearing in plasma or urine could only be derived from any labelled dose administered (Gregory \& Toth, 1988). However, further work showed that the appearance of labelled folate in plasma was greater for intravenous folates than for oral folates. Hence, it was suggested that absolute bioavailability could not be determined readily because of a presumed extensive hepatic uptake of absorbed folates from the oral dose (Rogers et al. 1997). Methods were then developed to avoid this limitation, based on a singledose dual-label approach in which two isotopically-labelled forms of folic acid $\left({ }^{13} \mathrm{C}\right.$ and $\left.{ }^{2} \mathrm{H}\right)$ are administered; one as an oral $\left({ }^{13} \mathrm{C}\right)$ dose and one as an intravenous $\left({ }^{2} \mathrm{H}\right)$ dose.

The percentage of the oral and intravenous doses excreted as intact folate in urine over a $24-48 \mathrm{~h}$ period was measured and then expressed as the urinary excretion ratio to estimate the fractional absorption of the oral dose (Rogers et al. 1997). However, the 'phenomenon' that some oral doses of folic acid exhibit a urinary excretion ratio higher than the theoretical maximum of 1.0 was also reported. Although it was confirmed later that the oral folic acid dose (absorbed and then transferred into the plasma as 5-methyl THF) and the intravenous folic acid dose (introduced into the plasma directly as folic acid) were handled differently, it was thought that this dual oral-intravenous approach would still have much merit once the circulating form of plasma folate,

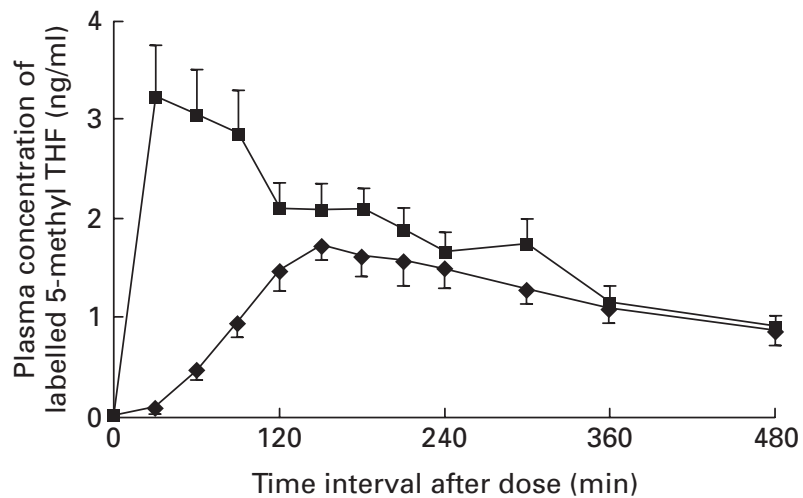

Fig. 2. Appearance of 5-methyltetrahydro[ $\left[{ }^{13} \mathrm{C}_{6}\right]$ folic acid in plasma following single oral dosing $(600 \mathrm{nmol})$ of fasted $(12 \mathrm{~h})$ human adult volunteers with 5 -formyltetrahydro[ $\left[{ }^{13} \mathrm{C}_{6}\right]$ folic acid $(\mathbf{\square}) ; n$ 10) and $\left[{ }^{13} \mathrm{C}_{6}\right]$ folic acid $(; n 12)$. Values are means with their standard errors represented by vertical bars. The labelled plasma response to the oral dose of folic acid was slower, and peaked much later (173 (SE 10) min v. 41 (SE 9) $\mathrm{min}$ ), than that to the 5-formyltetrahydrofolic acid test dose.

(6S-)5-methyl THF, was used for the intravenous dose (Finglas et al. 2002b).

The analysis of either isolated plasma or urine folate has been simplified recently. A previous, more cumbersome, GC-MS procedure that involved previous chemical cleavage of folates to their corresponding $p$-aminobenzoylglutamate and subsequent derivatization to a more volatile compound has been replaced by a more direct liquid chromatographyMS technique (Hart et al. 2002). Studies using direct measurement of plasma enrichment by the liquid chromatography-MS approach, combined with kinetic modelling of absorption curves, may offer an alternative for the improved quantification of folate bioavailability (Finglas et al. 2002a). Fig. 2 shows the appearance of 5-methyltetrahydro $\left[{ }^{13} \mathrm{C}_{6}\right]$ folic acid in plasma following oral dosing of fasted $(12 \mathrm{~h})$ adult volunteers with either 5-formyltetrahydro $\left[{ }^{13} \mathrm{C}_{6}\right]$ folic acid or $\left[{ }^{13} \mathrm{C}_{6}\right]$ folic acid. The in vivo kinetics and absorption profile appears to be different for folic acid compared with 5-formyltetrahydrofolic acid, with the plasma area-under-the-curve response to folic acid being slower, and peaking much later, than the response to the 5-formyltetrahydrofolic acid test dose. This difference would lead to spurious conclusions in bioavailability studies based on comparisons of oral doses of reduced 'labelled' folate (e.g. labelled food folate) $v$. a 'labelled' folic acid reference dose. It is speculated that this phenomenon may be due to a slower rate of mucosal processing of folic acid (involving an initial two-step reduction, first to dihydrofolic acid and then to tetrahydrofolic acid, before methylation) compared with 5-formyltetrahydrofolic acid (methylation only). This difference may result in a slower transfer of 5-methyl THF metabolite to the plasma, which will, when coupled with a similar clearance rate to that of 5-methyl THF metabolite derived from oral 5-formyltetrahydrofolic acid, result in a comparatively smaller labelled plasma area under the curve. 


\section{Genetic aspects}

Over recent years the enzyme methylenetetrahydrofolate reductase (MTHFR) has received much attention because of the presence of a common gene polymorphism within the population. This polymorphism is a thermo-labile enzyme variant that results in an enzyme activity of about $50 \%$ of the normal value. It is inherited as an autosomal recessive trait and has been identified as a $677 \mathrm{C} \rightarrow \mathrm{T}$ mutation resulting in an alanine to valine substitution (Frosst et al. 1995). It was found to be associated with increased plasma homocysteine and with possible increased risk of cardiovascular disease (Kang et al. 1991). The MTHFR enzyme, which is dependent on FAD (a riboflavin coenzyme), provides the 5-methyl THF necessary for the vitamin $\mathrm{B}_{12^{-}}$ dependent remethylation of homocysteine to methionine (Fig. 1). Thus, it is a crucial enzyme, as it can direct the folate pool towards homocysteine remethylation at the expense of DNA and RNA biosynthesis. The prevalence of the MTHFR $677 \mathrm{C} \rightarrow \mathrm{T}$ variant is related to ethnicity; the frequency of homozygosity for the $\mathrm{T}$ allele (abnormal TT genotype) is approximately $10-15 \%$ in the UK, $20-30 \%$ in some Italian populations, but only a few percent in Afro-Americans (Schneider et al. 1998).

The concentration of erythrocyte folate, used as an index of body stores, varies according to MTHFR $677 \mathrm{C} \rightarrow \mathrm{T}$ genotype, and appears to be related to the type of folate assay used. This relationship is explained by the different responses of the intracellular folate species to the various detection systems (Molloy et al. 1998), since it has been shown recently that formylated tetrahydrofolate polyglutamates may accumulate in 'TT' (MTHFR $677 \mathrm{C} \rightarrow \mathrm{T}$ ) subjects at the expense of 5-methyl THF, the predominant form in other wild-type (CC) and heterozygous (CT) individuals. These formyl forms may cause re-direction of $\mathrm{C}_{1}$ metabolism towards the more efficient maintenance of DNA repair under conditions of low folate intake or status (Bagley \& Sehub, 1998), since they are more associated with purine and pyrimidine synthesis than with methylation. However, it is clear that there is a lack of heterogeneity within 'TT' subjects, as the percentage of formyl folate may vary from $0 \%$ (i.e. $100 \%$ 'normal' 5-methyl THF) to $>60 \%$.

Other 'common' inherited enzyme polymorphisms intimately involved in deconjugation, transport and $\mathrm{C}_{1}$ metabolism are listed in Table 1 . These polymorphisms include: a second MTHFR deficiency $(1298 \mathrm{~A} \rightarrow \mathrm{C})$; methionine synthase deficiency $(2756 \mathrm{~A} \rightarrow \mathrm{G})$, a vitamin $\mathrm{B}_{12^{-}}$ dependent enzyme involved in remethylation of homocysteine to methionine (Silaste et al. 2001); methionine synthase reductase deficiency $(66 \mathrm{~A} \rightarrow \mathrm{G})$, a vitamin $\mathrm{B}_{2^{-}}$ dependent enzyme which regenerates methionine synthase (Wilson et al. 1999; Gaughan et al. 2001; Rady et al. 2002). Additionally, there are 'common' polymorphisms in the

Table 1. Common polymorphisms in folate-related absorption and metabolism (adapted from Molloy, 2002)

\begin{tabular}{|c|c|c|c|c|c|c|}
\hline Enzyme (gene mutation point) & $\begin{array}{l}\text { Mutation (\% allele } \\
\text { frequency) }\end{array}$ & $\begin{array}{l}\text { Wild-type } \\
(\%)\end{array}$ & $\begin{array}{l}\text { Heterozygous } \\
\text { defect (\%) }\end{array}$ & $\begin{array}{l}\text { Homozygous } \\
\text { defect }(\%)\end{array}$ & $\begin{array}{l}\text { Known risks or } \\
\text { phenotypic differences }\end{array}$ & Reference \\
\hline $\begin{array}{l}\text { Methylenetetrahydrofolate } \\
\text { reductase }(677 \mathrm{C} \rightarrow \mathrm{T})\end{array}$ & T 38 & CC 41 & CT 41 & TT 18 & $\begin{array}{l}\text { NTD, Down's syndrome, } \\
\text { cleft lip or palate, low } \\
\text { plasma or erythrocyte } \\
\text { folate, high plasma } \\
\text { homocysteine, } \\
\text { riboflavin-dependent }\end{array}$ & $\begin{array}{l}\text { Molloy et al. (1997), } \\
\text { Schneider et al. } \\
\text { (1998), Frosst et } \\
\text { al. (1995), Kang } \\
\text { et al. (1991), } \\
\text { Chango et al. } \\
\text { (2000) }\end{array}$ \\
\hline $\begin{array}{l}\text { Methylenetetrahydrofolate } \\
\text { reductase }(1289 \mathrm{~A} \rightarrow \mathrm{C})\end{array}$ & C 28 & AA 53 & $\mathrm{AC} 37$ & CC 9 & $\begin{array}{l}\text { Low plasma or erythrocyte } \\
\text { folate, high plasma } \\
\text { homocysteine, } \\
\text { riboflavin-dependent }\end{array}$ & $\begin{array}{l}\text { Dekou et al. (2001), } \\
\text { Silaste et al. } \\
(2001)\end{array}$ \\
\hline $\begin{array}{l}\text { Intestinal folate brush-border } \\
\text { hydrolase }(1561 \mathrm{C} \rightarrow \mathrm{T})\end{array}$ & $\mathrm{T} 4$ & CC 92 & CT 8 & $\begin{array}{l}\text { TT } 0 \text { (one in } \\
625 \text { ) }\end{array}$ & $\begin{array}{l}\text { Low plasma folate, high } \\
\text { plasma homocysteine } \\
\text { (predict lower } \\
\text { absorption) }\end{array}$ & Devlin et al. (2000) \\
\hline $\begin{array}{l}\text { Intestinal reduced folate } \\
\text { carrier }(80 \mathrm{~A} \rightarrow \mathrm{G})\end{array}$ & G 42 & AA 35 & AG 47 & GG 18 & $\begin{array}{l}\text { No change in erythrocyte } \\
\text { folate or plasma } \\
\text { homocysteine (predict } \\
\text { lower absorption) }\end{array}$ & $\begin{array}{l}\text { Chango et al. } \\
\qquad(2000), \text { Whets- } \\
\text { tine et al. (2001) }\end{array}$ \\
\hline $\begin{array}{l}\text { Methionine synthase } \\
\qquad(2756 \mathrm{~A} \rightarrow \mathrm{G})\end{array}$ & G 24 & AA 59 & AG 38 & GG 3 & $\begin{array}{l}\text { High plasma folate and } \\
\text { erythrocyte folate, } \\
\text { reduced plasma } \\
\text { homocysteine, vitamin } \\
\mathrm{B}_{12} \text {-dependent }\end{array}$ & $\begin{array}{l}\text { Silaste et al. (2001), } \\
\text { Chen et al. } \\
(2001)\end{array}$ \\
\hline $\begin{array}{l}\text { Methionine synthase } \\
\text { reductase }(66 \mathrm{~A} \rightarrow \mathrm{G})\end{array}$ & G 48 & AA 28 & AG 49 & GG 23 & $\begin{array}{l}\text { NTD, Down's syndrome, } \\
\text { higher plasma } \\
\text { homocysteine, } \\
\text { riboflavin-dependent }\end{array}$ & $\begin{array}{l}\text { Wilson et al. (1999), } \\
\text { Gaughan et al. } \\
\text { (2001), Rady } \\
\text { et al. (2002) }\end{array}$ \\
\hline $\begin{array}{l}\text { Cystathionine } \beta \text {-synthase } \\
\text { (844ins68) }\end{array}$ & 8 & 84 & 16 & 0 (lethal?) & $\begin{array}{l}\text { Higher plasma } \\
\text { homocysteine? vitamin } \\
\mathrm{B}_{6} \text {-dependent }\end{array}$ & $\begin{array}{l}\text { Tsai et al. (2001), } \\
\text { Silaste et al. } \\
(2001)\end{array}$ \\
\hline
\end{tabular}


intestinal folate brush-border hydrolase folylpolyglutamate carboxypeptidase $(1561 \mathrm{C} \rightarrow \mathrm{T}$; Devlin et al. 2000) and the intestinal reduced folate carrier $(80 \mathrm{~A} \rightarrow \mathrm{G}$; Whetstine et al. 2001).

Although several common genetic polymorphisms in folate-dependent enzymes have been implicated in the development of homocysteinaemia, and increased risk of neural-tube defects, it is not known precisely to what extent these genetic variants contribute to low folate intakes and disease risk in the general population. However, despite the growing body of research on the post-absorptive implications of these polymorphisms, there is very little information available on their influence on folate bioavailability and recommended intakes to maintain an optimal status in a diverse population group.

\section{Association of folate status and human health}

A low circulating folate concentration gives rise to an elevated plasma homocysteine concentration, which is an independent risk factor for several types of vascular disease and stroke (Kang et al. 1992; Boushey et al. 1995; Alfthan et al. 1997; Vollset et al. 2001; Quere et al. 2002) and neuro-psychiatric disturbances, including depression and dementia (Botiglieri, 1996). In one of a few 'prospective studies' the risk in Finnish men in the top third of serum folate concentrations was only $30 \%$ of the risk in the lowest third of serum folate concentrations (Voutilainen et al. 2000). Whilst elevated homocysteine has been accepted for some time as a 'risk marker', plausible metabolic mechanisms are beginning to emerge that may soon see its acceptance as a 'risk-factor'. It is currently suggested that elevated homocysteine may have direct proatherogenic effects mediated via cholesterol dysregulation (Li et al. 2002) and by the enhancement of monocyte and T-cell adhesion to human aortic endothelial cells (Koga et al. 2002). Although folic acid supplementation or fortification may be effective in lowering homocysteine concentrations, it is suggested that concurrent ingestion of vitamin $\mathrm{B}_{12}$ would be much more effective (Quinlivan et al. 2002).

Not only is low maternal folate status associated with increased risk for neural-tube defects (Daly et al. 1995) and cancer, e.g. colo-rectal cancer (Ryan \& Weir, 2001), but so is the common 'TT' polymorphism in the MTHFR $677 \mathrm{C} \rightarrow \mathrm{T}$ gene (Ou et al. 1996), particularly when combined with low folate status (Christensen et al. 1999). Both MTHFR $677 \mathrm{C} \rightarrow \mathrm{T}$ and methionine synthase reductase $66 \mathrm{~A} \rightarrow \mathrm{G}$ have been implicated in the incidence of Down's Syndrome (James et al. 1999; Hobbs et al. 2000).

The MTHFR $677 \mathrm{C} \rightarrow \mathrm{T}$ mutation may potentially have both positive and negative effects. It might enhance availability of methylenetetrahydrofolate in the DNA synthesis pathway, thus reducing misincorporation of uracil into DNA, which might otherwise result in double-strand breaks during uracil excision repair processes (Blount et al. 1997). Also, it might reduce both homocysteine remethylation and DNA methylation, which plays a role in genome stability and gene expression (Choi \& Mason, 2000; Friso et al. 2002). The ultimate question, of course, is whether such a common mutation reduces overall longevity. As yet, there has been little study of this aspect, and no consensus. There is both evidence of no overall effect (Brattstrom et al. 1999), and conflicting evidence that it reduces longevity in men in middle and old age, but not in women (Heijmans et al. 1999).

\section{Folic acid fortification}

In the UK over half the pregnancies are unplanned, and recommendations for women to increase their folate intakes, together with uncertainties of folate bioavailability, are difficult to implement. In the USA the fortification of all enriched grain products, such as flour, has resulted in a decrease of about $20 \%$ in the prevalence of neural-tube defects (Honein et al. 2001). It has also resulted in a population-wide increase in plasma and erythrocyte folate concentrations, together with a fall in plasma homocysteine of $48 \%$ in subjects with an elevated homocysteine concentration of $>13 \mu \mathrm{mol} / 1$ (Lawrence et al. 1999; Jacques et al. 1999). In 1998, following fortification, there was a $3.4 \%$ reduction in mortality from stroke and heart attack (Martin et al. 1999), which could possibly be linked to the fall in plasma homocysteine concentrations.

In the UK the Committee on Medical Aspects of Food and Nutrition Policy (Department of Health, 2000) has recommended a fortification policy of $2400 \mu \mathrm{g} / \mathrm{kg}$ flour, but this recommendation has not yet been implemented. The potential risk-benefits of introducing mandatory fortification of flour were recently reviewed (Wright et al. 2001) and it was considered that there are still a number of issues to be resolved; such as claims of an increased risk of dichorionic twin pregnancies and increases in MTHFR $667 \mathrm{C} \rightarrow \mathrm{T}$ gene frequency in newborns. Although folic acid is considered to be a very safe compound with no toxicity threshold (Campbell, 1996), it has been estimated that $20 \%$ of young children may exceed the newly-recommended tolerable upper intake level of $1 \mathrm{mg} / \mathrm{d}$ for their age-group (Lewis et al. 1999).

\section{Conclusions}

The discovery that folic acid supplementation before conception markedly reduces the risk of neural-tube defects represents a major achievement since the vitamin was discovered $>70$ years ago. There has been considerable progress in understanding the role of folic acid in health and disease, but there is still much to do in perfecting methods for measuring folate bioavailability, and status. Optimal folate status may confer a protective effect against many chronic diseases, and increasing folate intakes may be expected to reduce the prevalence of these folate-related diseases. However, the bioavailability of different folate vitamers is still not well understood. There are still a number of outstanding research issues that need to be resolved before a re-evaluation of optimal folate intakes can be undertaken. These issues include: (1) is folate status increased best by the intake of folate supplements, fortified foods or natural food folates; (2) is optimal folate status easily achievable in countries that do not permit the folic acid fortification of foodstuffs; (3) what are the health consequences of some sections of the population consuming large amounts of folic acid. 


\section{Acknowledgements}

The authors are supported by a strategic grant from the UK Biotechnology and Biological Sciences Research Council.

\section{References}

Alfthan G, Aro A \& Gey KF (1997) Plasma homocysteine and cardiovascular disease mortality. Lancet 349, 397.

Babu S \& Srikantia SG (1976) Availability of folates from some foods. American Journal of Clinical Nutrition 29, 376-379.

Bagley PJ \& Selhub J (1998) A common mutation in the methylenetetrahydrofolate reductase gene is associated with an accumulation of formylated tetrahydrofolates in red blood cells. Proceedings of the National Academy of Sciences USA 95, 13217-13220.

Bailey LB (1998) Dietary reference intakes for folate: The debut of dietary folate equivalents. Nutrition Reviews 56, 294-299.

Bailey LB, Cerda JJ, Bloch BS, Busby MJ, Vargas L, Chandler CJ \& Halsted CH (1984) Effects of age on poly- and monoglutamyl folacin absorption in human subjects. Journal of Nutrition 114, 1770-1776.

Blount BC, Mack MM, Wehr CM, MacGregor JT, Hiatt RA, Wang G, Wickramasinghe SN, Everson RB \& Ames BN (1997) Folate deficiency causes uracil misincorporation into human DNA and chromosome breakage: implications for cancer and neuronal damage. Proceedings of the National Academy of Sciences USA 94, 3290-3295.

Botiglieri T (1996) Folate, vitamin B12, and neuropsychiatric disorders. Nutrition Reviews 54, 382-390.

Boushey CJ, Beresford SAA, Omenn GS \& Motulsky AG (1995) A quantitative assessment of plasma homocysteine as a risk factor for vascular disease. Journal of the American Medical Association 274, 1049-1057.

Bower C, Stanley FJ, Croft M, De Clerk NH, Davis RE \& Nicol DJ (1993) Absorption of pteroylpolyglutamates in mothers of infants with neural tube defects. British Journal of Nutrition 69 , 827-834.

Brattstrom L, Zhang Y, Hurtig M, Refsum H, Ostensson S, Fransson L, Jones K, Landgren F, Brudin L \& Ueland PM (1999) A common methylenetetrahydrofolate reductase gene mutation and longevity. Atherosclerosis 146, 395-397.

Butterworth CE, Newman AJ \& Krumdieck CL (1974) Tropical sprue: a consideration of possible etiologic mechanism with emphasis on pteroyl polyglutamate metabolism. Transactions of the American Clinical and Climatological Association 86, $11-22$.

Campbell NR (1996) How safe are folic acid supplements? Archives of Internal Medicine 156, 1638-1644.

Chango A, Potier de Courcy G, Boisson F, Guillard JC, Barbe F, Perrin MO, Christides JP, Rabhi K, Pfister M, Galan P, Hercberg S \& Nicholas JP (2000) 5,10-methylenetetrahydrofolate reductase common mutations, folate status and plasma homocyseteine in healthy French adults of the Supplementation en Vitamines et Mineraux Antioxydants (SU.VI.MAX) cohort. British Journal of Nutrition 84, 891-896.

Chen J, Stampfer MJ, Ma J, Selhub J, Malinow MR, Hennekens CH \& Hunter DJ (2001) Influence of a methionine synthase (D919G) polymorphism on plasma homocysteine and folate levels and relation to risk of myocardial infarction. Atherosclerosis 154, 667-672.

Choi SW \& Mason JB (2000) Folate and carcinogenesis: an integrated scheme. Journal of Nutrition 130, 129-132.

Christensen B, Arbour L, Tran P, Leclerk D, Sabbaghian N, Platt R, Gilfix BM, Rosenblatt DS, Gravel RA, Forbes P \& Rozen R (1999) Genetic polymorphisms in methylenetetrahydrofolate reductase and methionine synthase, folate levels in red blood cells, and risk of neural tube defects. American Journal of Medical Genetics 84, 151-157.

Czeizel AE \& Dudas I (1992) Prevention of the first occurrence of neural-tube defects by periconceptional vitamin supplementation. New England Journal of Medicine 327, 1832-1835.

Daly LE, Kirke PN, Molloy A, Weir DG \& Scott JM (1995) Folate levels and neural tube defects. Implications for prevention. Journal of the American Medical Association 274, 1698-1702.

Dekou V, Whincup P, Papcosta O, Ebrahim S, Lennon L, Ueland PM, Refsum H, Humphries SE \& Gudnason V (2001) The effect of the C6777T and A1298C polymorphisms in the methylenetetrahydrofolate reductase gene on homocysteine levels in elderly men and women from the British regional heart study. Atherosclerosis 154, 659-699.

Department of Health and Social Security (1979) Recommended Daily Amounts of Food Energy and Nutrients for Groups of People in the United Kingdom. Report on Health and Social Subjects no. 15. London: H.M. Stationery Office.

Department of Health (1991) Dietary Reference Values for Food Energy and Nutrients for the United Kingdom. Report on Health and Social Subjects no. 41. London: H.M. Stationery Office.

Department of Health (2000) Folic Acid and the Prevention of Disease. Report on Health and Social Subjects no. 50. London: The Stationery Office.

Devlin AM, Ling E-H, Peerson JM, Fernando S, Clarke R, Smith DA \& Halsted CH (2000) Glutamate carboxypeptidase II: a polymorphism associated with lower levels of serum folate and hyperhomocysteinemia. Human Molecular Genetics 9, 2837-2844.

Finglas PM, Dainty JR, Hart D, Wolfe C, Wright AJA, Southon S \& Gregory JF (2002a) Modelling of labelled absorbed folates using plasma in humans. FASEB Journal 16, A748.

Finglas PM, Witthöft CM, Vahteristo L, Wright AJA, Southon S, Mellon F, Ridge B \& Maunder P (2002b). Use of an oral/ intravenous dual-label stable-isotope protocol to determine folic acid bioavailability from fortified cereal grain foods in women. Journal of Nutrition 132, 936-939.

Friso S, Choi SW, Girelli D, Mason JB, Dolnikowski GG, Bagley PJ, Oliveri O, Jaques PF, Rosenburg IH, Corrocher R \& Selhub J (2002) A common mutation in the 5,10-methylenetetrahydrofolate reductase gene affects genomic DNA methylation through an interaction with folate status. Proceedings of the National Academy of Sciences USA 99, 5606-5611.

Frosst P, Blom HJ, Milos R, Goyette P, Sheppard CA, Matthews RG, Boers GJH, den Heijer M, Kluijtmans LAJ, van den Heuvel LP \& Rozen R (1995) A candidate genetic risk factor for vascular disease: a common mutation in methylenetetrahydrofolate reductase. Nature Genetics 10, 111-113.

Gaughan DJ, Kluijtmans LAJ, Barbaux S, McMaster D, Young IS, Yarnell JWG, Evans A \& Whitehead AS (2001) The methionine synthase reductase (MTRR) A66G polymorphism is a novel genetic determinant of plasma homocysteine concentrations. Atherosclerosis 157, 451-456.

Ghitis J (1967) The folate binding in milk. American Journal of Clinical Nutrition 20, 1-4.

Gregory JF \& Toth JP (1988) Chemical synthesis of deuterated folate monoglutamate and in vivo assessment of urinary excretion of deuterated folates in man. Analytical Biochemistry 170, 94-104.

Gregory JF III (1997) Bioavailability of folate. European Journal of Clinical Nutrition 51, S54-S59.

Gregory JF III (2001) Case study: Folate bioavailability. Journal of Nutrition 131, 1376S-1382S.

Halsted CM (1980) Intestinal absorption and malabsorption of folates. Annual Review of Medicine 31, 79-87.

Hart DJ, Finglas PM, Wolfe CA, Mellon F, Wright AJA \& Southon S (2002) Determination of 5-methyltetrahydrofolate 
(13C-labelled and unlabelled) in human plasma and urine by combined liquid chromatography mass spectrometry (LC/MS). Analytical Biochemistry 305, 206-213.

Heijmans BT, Gussekloo J, Kluft C, Droog S, Lagaay AM, Knook DL, Westendorp RG \& Slagboom EP (1999) Mortality risk in men is associated with a common mutation in the methylenetetrahydrofolate reductase gene (MTHFR). European Journal of Human Genetics 7, 197-204.

Herbert V \& Das KC (1993) Folic acid and vitamin B12. In Modern Nutrition in Health and Disease, 8th ed., pp. 402-425 [ME Shils, JA Olson and M Shike, editors]. PhiladelphiA, PA: Lea \& Febiger.

Hobbs CA, Sherman SL Yi P, Hopkins SE, Torfs CP, Hine RJ, Pogribna M, Rozen R \& James SJ (2000) Polymorphisms in genes involved in folate metabolism as maternal risk factors for Down syndrome. American Journal of Human Genetics 67 , 623-630.

Honein MA, Paulozzi LJ, Mathews TJ, Ericksen DJ \& Wong L-YC (2001) Impact of folic acid fortification of the US food supply on the occurrence of neural tube defects. Journal of the American Medical Association 285, 2981-2986.

Hoppner K \& Lampi B (1980) Folate levels in human liver autopsies in Canada. American Journal of Clinical Nutrition 33, 862-864.

Institute of Medicine (2000) Dietary Reference Intakes for Thiamine, Riboflavin, Niacin, Vitamin B6, Folate, Vitamin B12, Pantothenic Acid, Biotin and Choline. Washington, DC: National Academy Press.

Jacques PF, Selhub J, Bostom AG, Wilson PW \& Rosenberg IH (1999) The effect of folic acid fortification on plasma folate and total homocysteine concentration. New England Journal of Medicine 340, 1449-1454.

James SJ, Pogribna M, Porgribny IP, Melnyk S, Hine RJ, Gibson JB, Yi P, Tafoya DL, Swenson DH, Wilson VL \& Gaylor DW (1999) Abnormal folate metabolism and mutation in the methylenetetrahydrofolate reductase gene may be maternal risk factors for Down syndrome. American Journal of Clinical Nutrition 70, 495-501.

Kang SS, Wong PW, Susmano A, Sora J, Norusis M \& Ruggie N (1991) Thermolabile methylenetetrahydrofolate reductase: an inherited risk factor for coronary artery disease. American Journal of Human Genetics 48, 536-545.

Kang SS, Wong PWK \& Malinow MR (1992) Hyperhomocysteinemia as a risk factor for occlusive vascular disease. Annual Review of Nutrition 12, 279-298.

Kelly P, McPartlin J, Goggins M, Weir DG \& Scott JM (1997) Unmetabolised folic acid in serum: acute studies in subjects consuming fortified food and supplements. American Journal of Clinical Nutrition 65, 1790-1795.

Koga T, Claycombe K \& Meydani O (2002) Homocysteine increases monocyte and T-cell adhesion to human aortic endothelial cells. Atherosclerosis 161, 365-374.

Konings EJM, Troost FJ, Castenmiller JJM, Roomans HHS, van den Brandt PA \& Saris WHM (2002) Intestinal absorption of different types of folate in healthy subjects with an ileostomy. British Journal of Nutrition 88, 235-242.

Lawrence JM, Petitti DB, Watkins M \& Umekubo MA (1999) Trends in serum folate after food fortification. Lancet $\mathbf{3 5 4}$, 915-916.

Lewis CJ, Crane NT, Wilson DB \& Yetley EA (1999) Estimated folate intakes: data updated to reflect food fortification, increased bioavailability and dietary supplement use. American Journal of Clinical Nutrition 70, 198-207.

Li H, Lewis A, Brodsky S, Reiger R, Iden C \& Gologorsky MS (2002) Homocysteine induces 3-hydroxy-3-methylglutaryl coenzyme A reductase in vascular endothelial cells: a mechanism for development of atherosclerosis? Circulation 105, 1037-1043.
Lucock MD, Wild J, Smithells RW \& Hartley R (1989) In vivo characterization of the absorption and biotransformation of pteroylmonoglutamic acid in man: a model for future studies. Biochemical Medicine and Metabolic Biology 42, 30-42.

Martin JA, Smith BL, Mathews TJ \& Ventura MA (1999) Births and deaths: preliminary data for 1998. National Vital Statistics Reports 47, 1-45.

Mason JB (1995) Folate status: effects on carcinogensis. In Folate in Health and Disease, pp. 361-378 [LB Bailey, editor]. New York: Marcel Dekker.

Mitchell HK, Snell EE \& Williams RJ (1941) The concentration of 'folic acid'. Journal of the American Chemistry Society 63, 2284.

Molloy AM (2002) Folate bioavailability and health. International Journal of Vitamin and Nutrition Research 72, 46-52.

Molloy AM, Daly S, Mills JL, Kirke PN, Whitehead AS, Ramsbottom D, Conley MR, Weir DG \& Scott JM (1997) Thermolabile varient of 5,10-methylenetetrahydrofolate reductase associated with low red cell folates: implications for folate intake recommendations. Lancet 349, 1591-1593.

Molloy AM, Mills JL, Kirke PN, Whitehead AS, Weir DG \& Scott JM (1998) Whole-blood folate values in subjects with different methylenetetrahydrofolate reductase genotypes: Differences between the radioassay and microbiological assays. Clinical Chemistry 44, 186-188.

MRC Vitamin Study Research Group (1991) Prevention of neural tube defects: Results of the Medical Research Council Vitamin Study. Lancet 338, 131-137.

Ou CY, Stevenson RE, Brown VK, Schwartz CE, Allen WP, Khoury MJ, Rozen R, Oakley GP \& Adams MJ Jr (1996) 5,10 Methylenetetrahydrofolate reductase genetic polymorphism as a risk factor for neural tube defects. American Journal of Medical Genetics 63, 610-614.

Perry J \& Chanarin I (1972) Observations on folate absorption with particular reference to folate polyglutamate and possible inhibitors to its absorption. Gut 13, 544-550.

Pietrzik K, Hages M \& Remer T (1990) Methodological aspects in vitamin bioavailability testing. Journal of Micronutrient Analysis 7, 207-222.

Prinz-Langenohl R, Bronstrup A, Thorand B, Hages M \& Pietrzik K (1999) Availability of food folate in humans. Journal of Nutrition 129, 913-916.

Quere I, Perneger TV, Zittoun J, Bellet H, Gris J-C, Daures J-P, Schved J-F, Mercier E, Laroche J-P, Dauzat M, Bounameaux H, Janbon C \& de Moerloose P (2002) Red blood cell methyfolate and plasma homocysteine as risk factors for venous thromboembolism: a matched case-control study. Lancet 359, 747-752.

Quinlivan EP, McPartlin J, McNulty H, Ward M, Strain JJ, Weir DG \& Scott JM (2002) Importance of both folic acid and vitamin B12 in reduction of risk of vascular disease. Lancet $\mathbf{3 5 9}$, 227-228.

Rady PL, Szucs S, Grady J, Hudnall SD, Kellner LH, Nitowsky H, Tyring SK \& Matalon RK (2002) Genetic polymorphisms of methylenetetrahydrofolate reductase (MTHFR) and methionine synthase reductase (MTRR) in ethnic populations in Texas; a report of a novel MTHFR polymorphic site, G1793A. American Journal of Medical Genetics 107, 162-168.

Reisenauer AM, Krumdieck CL \& Halsted CH (1977) Folate conjugase: two separate activities in human jejunum. Science 198, 196-197.

Rogers LM, Pfeiffer CM, Bailey LB \& Gregory JF (1997) A duallabel stable isotopic protocol is suitable for determination of folate bioavailabiltiy in humans: evaluation of urinary excretion and plasma folate kinetics of intravenous and oral doses of $\left[{ }^{13} \mathrm{C}_{5}\right]$ and $\left[{ }^{2} \mathrm{H}_{2}\right]$ folic acid. Journal of Nutrition 127, 2321-2327.

Russell RM, Dahr GJ, Dutta SK \& Rosenburg IH (1979) Influence of intraluminal $\mathrm{pH}$ on folate absorption. Studies in control 
subjects and in patients with pancreatic insufficiency. Journal of laboratory and Clinical Medicine 93, 428-436.

Ryan BM \& Weir DG (2001) Relevance of folate metabolism in the pathogenesis of colorectal cancer. Journal of Laboratory and Clinical Medicine 138, 164-176.

Schneider JA, Rees DC, Liu Y-T \& Clegg JB (1998) Worldwide distribution of a common methylenetetrahydrofolate reductase mutation. American Journal of Human Genetics 62, 1258-1260.

Scott JM (1999) Folate and vitamin $\mathrm{B}_{12}$. Proceedings of the Nutrition Society 58, 441-448.

Selhub J, Dhar GJ \& Rosenburg IH (1983) Gastrointestinal absorption of folates and antifolates. Pharmacology and Therapeutics 20, 397-418.

Selhub J, Powell GM \& Rosenburg IH (1984). Intestinal transport of 5-methyltetrahydrofolate. American Journal of Physiology 246, G515-G520.

Silaste M-L, Rantala M, Sampi M, Alfthan G, Aro A \& Kesaniemi A (2001) Polymorphisms of key enzymes in homocysteine metabolism affect diet responsiveness of plasma homocysteine in healthy women. Journal of Nutrition 131, 2643-2647.

Steinberg SE, Campbell CL \& Hillman RS (1979) Kinetics of the normal folate enterohepatic cycle. Journal of Clinical Investigation 64, 83-88.

Tamura T \& Stokstad ELR (1973) The availability of food folate in man. British Journal of Haematology 25, 513-532.

Tsai MY, Bignell M, Yang F, Welge BG, Graham KJ \& Hanson NQ (2001) Polygenic influence on plasma homocysteine: association of two prevalent mutations, the 844ins68 of cystathione beta-synthase and A(2756)G of methionine synthase, with lowered plasma homocysteine levels. Atherosclerosis 149, 131-137.

Vollset SE, Refsum H, Tverdal A, Nygard O, Nordrehaug JE, Tell GS \& Ueland PM (2001) Plasma total homocysteine and cardiovascular and noncardiovascular mortality: the Hordaland homocysteine study. American Journal of Clinical Nutrition $\mathbf{7 4}$ $130-136$

Voutilainen S, Lakka TA, Porkkala-Sarataho E, Rissanen T, Kaplan GA \& Salonen JT (2000) Low serum folate concentrations are associated with an excess incidence of acute coronary events: the Kuopio Ischaemic Heart Disease Risk Factor Study. European Journal of Clinical Nutrition 54, 424-428.

Wagner C (1985) Folate-binding proteins. Nutrition Reviews 43, 293-299.

Wagner C (1996) Symposium on the subcellular compartmentation of folate metabolism. Journal of Nutrition 126, 1228S-1234S.

Weir DG, McGing PG \& Scott JM (1985) Commentary: Folate metabolism, the enterohepatic circulation and alcohol. Biochemical Pharmacology 34, 1-7.

Whetstine JR, Gifford AJ, Witt T, Liu XY, Flatley RM, Norris M, Haber M, Taub JW, Ravindranath Y \& Matherly LH (2001) Single nucleotide polymorphisms in the human reduced folate carrier: characterization of a high-frequency G/A variant at position 80 and transport properties of the $\mathrm{His}^{27}$ and $\mathrm{Arg}^{27}$ carriers. Clinical Cancer Research 7, 3416-3422.

Whitehead VM (1973) Polygammaglutamyl metabolites of folic acid in humans liver. Lancet i, 743-745.

Wills L (1931) Treatment of 'pernicious anaemia of pregnancy' and 'tropical anaemia' with special reference to yeast extract as a curative agent. British Medical Journal 1, 1059-1064.

Wilson A, Platt R, Wu Q, Leclerc D, Christensen B, Yang H, Gravel RA \& Rozen R (1999) A common variant in methionine synthase reductase combined with low cobalamin (vitamin B-12) increases risk for spina bifida. Molecular Genetics and Metabolism 67, 317-323.

Wright AJA, Finglas PM \& Southon S (2001) Proposed mandatory fortification of the UK diet with folic acid: have potential risks been underestimated. Trends in Food Science and Technology 12, 313-321. 